\title{
MOWING AND LOWERING THE MARANDU PALISADEGRASS SWARD HEIGHT AT LATE WINTER IMPROVE THE SWARD STRUCTURE
}

\author{
A ROÇADA E A REDUÇÃO DA ALTURA DO CAPIM-MARANDU NO FINAL DO \\ INVERNO MELHORA A ESTRUTURA DO PASTO
}

\author{
Manoel Eduardo Rozalino SANTOS ${ }^{1 *}$, Bruno Humberto Rezende CARVALHO ${ }^{1}$; \\ Henrique Cesar Rodrigues NOGUEIRA ${ }^{\mathbf{1}}$; Gabriel de Oliveira ROCHA ${ }^{\mathbf{1}}$; \\ Flávia de Oliveira Scarpino VAN CLEEF ${ }^{2}$; Gustavo Segatto BORGES ${ }^{1}$; \\ Bruno Gomes BORGES ${ }^{1}$; Hélio Henrique VILELA ${ }^{3}$ \\ 1. Faculty of Veterinary Medicine, Federal University of Uberlândia, Uberlândia, MG, Brazil. manoel.rozalino@ufu.br. 2. Animal \\ Science Departament, University of Florida, North Florida Research and Education Center, Marianna, FL, USA. 3. Animal Science \\ Departament, University Center of Patos de Minas, Patos de Minas, MG, Brazil.
}

\begin{abstract}
The structure of the sward is important because it influences the responses of plants and animals in grazing conditions. The objective with this work was to evaluate the structural characteristics of the Marandu palisade grass pasture (Brachiaria brizantha syn. Urochloa brizantha) during spring and summer, depending on the condition of the sward at the end of winter. Four grazing conditions at the end of winter were evaluated: short $(24.1 \mathrm{~cm})$, short $(25.2 \mathrm{~cm}) /$ mown $(8 \mathrm{~cm})$, tall $(49.0 \mathrm{~cm})$ and tall $(50.0 \mathrm{~cm}) /$ mown $(8 \mathrm{~cm})$. The foliar area index was lower in the tall pasture than in the tall/mown pasture. The mass and the volumetric density of dead stem were higher in the tall pasture, intermediate in the short pasture, and lower in mowed pastures. At the beginning of the grazing period, the live stem mass was higher in the tall pasture. At the beginning and middle of the grazing period, the volumetric density of dead leaf lamina was lower in mowed pastures. At the beginning of the pasture period, the short pasture had a higher tiller number (TN). In the middle of the grazing period, the short and short/mown pastures had higher TN. At the end of the pasture period, the lowest TN value occurred in the tall pasture. The tall pasture at the end of winter presents an unfavorable structure to the animal in grazing, while the mowing and reduction in the height of the marandu palisade grass improves the structure of the sward in spring and summer.
\end{abstract}

KEYWORDS: Brachiaria brizantha syn. Forage mass. Herbage bulk density. Leaf area index. Tiller number. Urochloa brizantha.

\section{INTRODUCTION}

Sward structure is defined as the arrangement and spatial distribution of parts of above ground plant within their community (PEREIRA et al., 2010), which influences in the light interception and, in effect, the photosynthesis of forage canopy (PEDREIRA; PEDREIRA, 2007; PERI et al., 2003). In addition, the sward structure changes the microclimate inside the canopy and has consequence on the tillering dynamic (COSTA et al., 2016; PESSOA et al., 2016) and on the growth of the individual tiller (PAULA et al., 2012; PEREIRA et al., 2018). Regarding the animal, the sward structure is important because it determines the degree of ease on which the forage is digested during grazing and, consequently, influences the animal performance (CARVALHO et al., 2015). Therefore, it is relevant to investigate the factors that interfere with the sward structure.
After the implementation of the management strategy, forage plants develop in posterior seasons with morphogenic patterns determined by the previous management of the sward. This is due, in part, to the gradual phenotypic plasticity of the forage plant (NELSON, 2000). In this context, it is important to recognize that the current sward structure is also a consequence of sward management strategies adopted in previous seasons (SANTOS et al., 2015; SANTOS et al., 2017). These results, temporally, in a more ample horizon for assessing pasture management, an aspect that still requires scientific research.

In this context, the strategies of management used during the dry season in pastures submitted to deferred grazing may modify its structure for the subsequent rainy season. In fact, variations in heights of the sward of deferred pastures during late winter interfere with tillering (SANTANA et al., 2014) and, indeed, with the sward structure during spring (SOUSA et al., 2018). 
Likewise, the mowing of tall pastures during late winter results in the elimination of dead and old tillers, which also modifies the sward structure for the next season (SOUZA et al., 2015).

Marandu palisadegrass (Brachiaria brizantha) is one of the most used tropical forage grass species in Brazil (PEREIRA et al., 2010) and little knowledge is available on its structural characteristics during spring and summer due to the condition of the pasture during the previous winter. Within this context, this study was conducted to provide an answer to the question: "how does the mowing and sward height at the late winter influence the structure of the marandu palisadegrass in the rainy season?". It was hypothesized that: (1) tall pastures at the late winter compromise the sward structure during spring and early summer; and (2) the mowing of the tall pasture at the late winter improve the sward structure from spring.

\section{MATERIAL AND METHODS}

This study was carried out from March 2014 to February 2015, at the Capim-branco Experimental Farm in the Federal University of Uberlândia, in Uberlândia, MG (18²53'19 " south latitude; $48^{\circ} 20^{\prime} 57$ " longitude west; $776 \mathrm{~m}$ altitude). The experimental area consisted of twelve paddocks (experimental units) of $800 \mathrm{~m}^{2}$ each, with a pasture of Brachiaria brizantha syn. Urochloa brizantha cv. Marandu (marandu palisadegrass).

The area climate is Aw-type (ALVARES et al., 2013), tropical savannah with a dry winter season, with an average annual temperature and precipitation of $22.3{ }^{\circ} \mathrm{C}$ and $1,584 \mathrm{~mm}$. The climatic conditions during the experimental period were monitored at a meteorological station, located about $100 \mathrm{~m}$ from the experimental area (Figure 1).

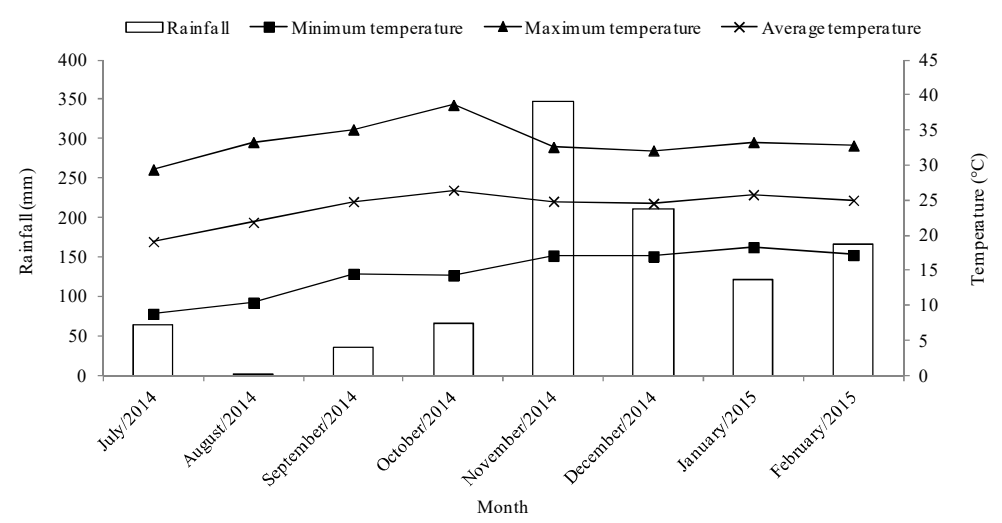

Figure 1. Accumulated rainfall, and minimum, average and maximum daily temperatures from July 2014 to February 2015.

The mean temperature and monthly precipitation were used to calculate the soil water balance (THORNTHWAITE; MATHER, 1955), considering a soil water storage capacity of $40 \mathrm{~mm}$ (Figure 2).

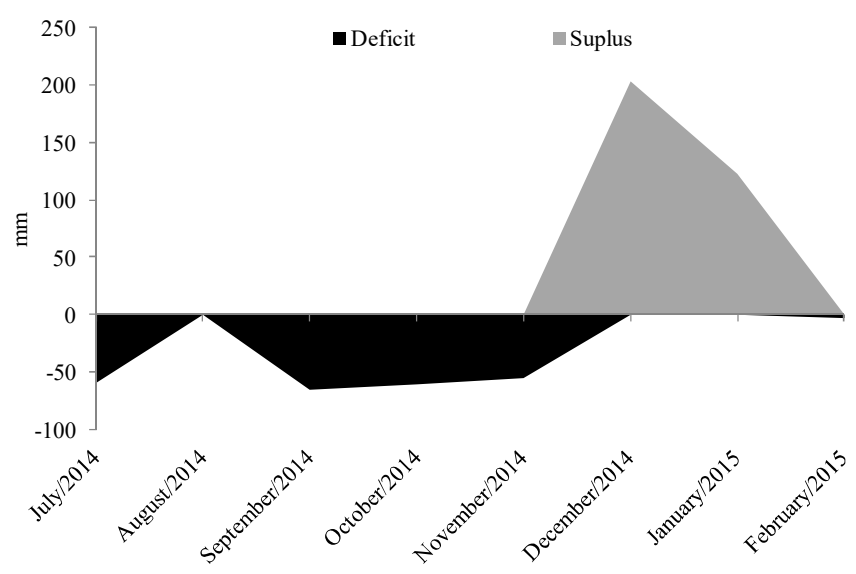

Figure 2. Water soil balance of the experimental area from July 2014 to February 2015. 
The soil of the experimental area had the following characteristics in the $0-20 \mathrm{~cm}$ layer: $\mathrm{pH}$ in $\mathrm{H}_{2} \mathrm{O}$ : 5.8; P: 4.5 (Mehlich-1) and $\mathrm{K}: 118.1 \mathrm{mg} \mathrm{dm}^{-3}$; $\mathrm{Ca}^{2+}: 4.9 ; \mathrm{Mg}^{2+}: 2.1$ and $\mathrm{Al}^{3+}: 0 \mathrm{cmol}_{\mathrm{c}} \mathrm{dm}^{-3}$. Based on these results $50 \mathrm{~kg} \mathrm{ha}^{-1}$ of $\mathrm{N}$ (as in urea) and $\mathrm{P}_{2} \mathrm{O}_{5}$ (as in single superphosphate) were applied in January 2014. Another application of $50 \mathrm{~kg} \mathrm{ha}^{-1}$ of $\mathrm{N}$ (as in urea) occurred in March 2014.

From January 2014 onwards, all the paddocks were managed under continuous stocking with sheep to maintain the average heights of the pastures at $30 \mathrm{~cm}$ (DA SILVA et al., 2013). In March 2014, the stocking rate was increased in order to reduce the sward height to $15 \mathrm{~cm}$ in 3 paddocks, and to $25 \mathrm{~cm}$ in the other 3 paddocks. On the other hand, the stocking rate was reduced to increase the sward height to $35 \mathrm{~cm}$ in 3 paddocks, and to $45 \mathrm{~cm}$ in 3 other paddocks. Thus, on March 17,2014 , all pastures were deferred at four initial heights $(15,25,35$ and $45 \mathrm{~cm})$ for 92 days. On $06 / 17 / 2014$ the grazing of the paddocks was initiated, where the pastures were managed under continuous stocking and fixed stocking rate with sheep (initial stocking rate of $4.0 \mathrm{UA} \mathrm{ha}^{-1}$ in all paddocks).

The grazing period of all deferred pastures lasted 82 days, and in 09/07/2014 (late winter), the pastures initially deferred at 15 and at $25 \mathrm{~cm}$ were at $24.1 \mathrm{~cm}$ and $25.2 \mathrm{~cm}$ respectively, with a forage mass of 2,420 and 2,198 $\mathrm{kg} \mathrm{ha}^{-1}$ of DM. Pastures deferred at 35 and $45 \mathrm{~cm}$ were taller and presented more forage mass during late winter $(49 \mathrm{~cm}$ and $3,837 \mathrm{~kg} \mathrm{ha}^{-1}$ of DM, and $50 \mathrm{~cm}$ and $4,211 \mathrm{~kg} \mathrm{ha}^{-1}$ of $\mathrm{DM}$, respectively). Thus, in order to cause a difference between pastures deferred at 35 and 45 $\mathrm{cm}$, the pasture deferred at $45 \mathrm{~cm}$ was mowed to 8 $\mathrm{cm}$ on $09 / 17 / 2014$, and the forage cut was not removed from the paddocks. Likewise, to cause a difference between pastures deferred at 15 and 25 $\mathrm{cm}$, the $25 \mathrm{~cm}$ height pasture was also mowed on the same date and with a similar post-cut height. Consequently, it was possible to obtain four sward conditions during late winter: short, short/mown, tall and tall/mown, which were evaluated during the beginning, middle and end of the grazing period in the subsequently spring and early summer.

From 09/07/2014 onwards, all pastures remained without animals for 75 days, until new tillers from the spring regrowth reached the heights of about $35 \mathrm{~cm}$, when the grazing period started, from $11 / 21 / 2014$ to $02 / 20 / 2015$ (91 days). During the grazing period, all pastures were managed under continuous stocking and variable stocking rate (MOTT; LUCAS, 1952), in order to maintain the average height between 30 and $35 \mathrm{~cm}$ (DA SILVA et al., 2013). The animals used in this period were crossbred Santa Ines x Dorper sheep, with $30 \mathrm{~kg}$ of body weight, which had unrestricted access only to mineral salt. The measurements of the sward height were performed twice a week at 30 random points per paddock, based on the distance from the soil surface to the apex of the highest leaf lamina located in the canopy.

In the beginning (first week), middle (12/17 to 20/2013) and end (02/03 and 04/2014) of the grazing period, all pastures assessments were performed. The mass of the morphological components of the pastures was obtained by cutting all the tillers, at the soil level, contained within a square of $0.25 \mathrm{~m}^{2}$ in three areas per paddock, with an average sward height. Each sample was weighed and split into two sub-samples. One of them was placed in a paper bag, dried in an air-forced oven at $65^{\circ} \mathrm{C}$ for 72 hours, and re-weighed. The other subsample was divided into its morphological components (live leaf lamina, live stem, dead leaf lamina and dead stem). The part of the leaf lamina that did not show signs of senescence was considered to be the live leaf lamina. The parts of the stem and leaf blade senescent, with yellowing and, or, organ necrosis, were incorporated into the fractions of dead stem and dead leaf lamina, respectively. After separation, the components were oven-dried $\left(65^{\circ} \mathrm{C}\right.$ for 72 hours) and weighed. Later, the masses of the morphological components of the pastures were calculated. The bulk densities of the pasture morphological components were calculated by dividing the morphological components masses by the average sward surface height.

The number of basal and live tiller of the pastures was quantified by counting the tillers within a rectangle of $25 \mathrm{~cm}$ by $50 \mathrm{~cm}$. Three counts per experimental unit (paddock) were performed in places where the plants were of the same average sward height. In each paddock, 50 live leaf lamina were randomly collected. A small portion of the ends of these leaves blades (apex and base) were cut and discarded, so that a rectangular leaf segment was obtained. The width and length of each segment were measured and, based on the product of these dimensions, the leaf area of the leaf segments was obtained. These leaves were placed in an air-forced oven at $65{ }^{\circ} \mathrm{C}$ for 72 hours and then weighed. The specific leaf area was calculated by dividing the area of all leaf segments by their weight. The leaf area index was obtained by multiplying the specific leaf area by the live leaf lamina mass of the pastures.

The variance analysis was performed in a completely randomized design using the SAS Proc Mixed. The covariance matrices were chosen using 
the Akaike information criterion (WOLFINGER, 1993). The effects of sward conditions, grazing period and their interaction were considered as fixed. Grazing periods were considered to be measurements that were repeated over time. The data were compared using the Tukey test $(\mathrm{P}<0.05)$.

\section{RESULTS}

Among the variables analyzed, only three (leaf area index, mass and bulk density of dead stem) were separately influenced by the pastures conditions during late winter and by the grazing period (Tables 1 and 2). The other seven characteristics were influenced by the interaction between the studied factors (Tables 3 and 4).

The sward height did not vary among the pastures conditions, but was lower in the end ( 28.8
SANTOS, M. E. R. et al.

$\mathrm{cm})$ than in the beginning $(37.8 \mathrm{~cm})$ and in the middle $(34.2 \mathrm{~cm})$ of the grazing period. For these last two periods, no difference was observed among the sward height values.

The leaf area index (LAI) was lower in the tall pasture than in the tall/mown pasture. The mass and bulk density of dead stems were bigger in the tall pasture, intermediate in the short pasture and lower in the short/mown and tall/mown pastures (Table 1).

Table 1. Structural characteristics of marandu palisadegrass pasture in spring and summer according to the sward condition at the late winter

\begin{tabular}{llllll}
\hline \multirow{2}{*}{ Characteristic } & \multicolumn{3}{c}{ Sward condition at late winter } & \multirow{2}{*}{ SEM $^{*}$} \\
\cline { 2 - 5 } & Short & Short/mown & Tall & Tall/mown & \\
\hline LAI & $2.5 \mathrm{ab}$ & $2.9 \mathrm{a}$ & $1.9 \mathrm{~b}$ & $3.1 \mathrm{a}$ & 0.26 \\
DSM & $404 \mathrm{~b}$ & $110 \mathrm{c}$ & $904 \mathrm{a}$ & $155 \mathrm{c}$ & 182 \\
BDDS & $12.7 \mathrm{~b}$ & $3.8 \mathrm{c}$ & $29.3 \mathrm{a}$ & $4.8 \mathrm{c}$ & 5,90 \\
\hline
\end{tabular}

*SEM: standard error of the mean: LAI: leaf area index; DSM: dead stem mass (kg ha ${ }^{-1}$ of DM); BDDS: bulk density of dead stem (kg ha.cm ${ }^{-1}$ of DM); for each characteristic, average followed by different letters differ by Tukey test $(\mathrm{P}<0.05)$.

The LAI was bigger in the beginning than in the middle and in the end of the grazing period, a response pattern contrary to that verified for the mass and the bulk density of dead stem (Table 2).

Table 2. Structural characteristics of marandu palisadegrass pastures during the grazing period in spring and summer

\begin{tabular}{lllll}
\hline \multirow{2}{*}{ Characteristic } & Grazing period & & \multirow{2}{*}{ SEM $^{*}$} \\
\cline { 2 - 3 } & Beginning & Middle & End & \\
LAI & $3.0 \mathrm{a}$ & $2.5 \mathrm{~b}$ & $2.3 \mathrm{~b}$ & 0.21 \\
DSM & $238 \mathrm{~b}$ & $279 \mathrm{~b}$ & $663 \mathrm{a}$ & 135 \\
BDDS & $6.1 \mathrm{~b}$ & $8.6 \mathrm{~b}$ & $23.3 \mathrm{a}$ & 5.37 \\
\hline
\end{tabular}

*SEM: standard error of the mean; LAI: leaf area index; DSM: dead stem mass (kg ha ${ }^{-1}$ of DM); BDDS: bulk density of dead stem (kg ha. $\mathrm{cm}^{-1}$ of DM); for each characteristic, average followed by different letters differ by Tukey test $(\mathrm{P}<0.05)$.

The live leaf lamina mass (LLLM) was lower in the end of the grazing period than in the beginning, with the exception of the tall/mown pasture, whose LLLM did not vary during the grazing period. In the beginning and in the middle of the grazing period, the tall pasture presented bigger LLLM than the others. However, in the end of the grazing period, the tall/mown pasture had the greatest value for this characteristic (Table 3). This same response pattern occurs for the bulk density of the live leaf lamina (Table 4). 
Table 3. Mass of morphological components and tiller number in marandu palisadegrass pastures during the grazing period in spring and summer and according to the sward condition during late winter

\begin{tabular}{|c|c|c|c|c|c|}
\hline \multirow{2}{*}{ Grazing period } & \multicolumn{4}{|c|}{ Sward condition at late winter } & \multirow[b]{2}{*}{ EM* } \\
\hline & Short & Short $/ \mathrm{mow}$ & Tall & Tall/mown & \\
\hline & \multicolumn{4}{|c|}{ Live leaf lamina mass $\left(\mathrm{kg} \mathrm{ha}^{-1}\right.$ of dry matter - DM) } & \multirow{5}{*}{97.8} \\
\hline Beginning & $1,355 \mathrm{bA}$ & $1,263 \mathrm{bA}$ & $1,751 \mathrm{aA}$ & $1,122 \mathrm{bA}$ & \\
\hline Middle & $1,066 \mathrm{bB}$ & $1,084 \mathrm{bAB}$ & $1,330 \mathrm{aA}$ & $1,003 \mathrm{bA}$ & \\
\hline End & $417 \mathrm{bC}$ & $554 \mathrm{bB}$ & $460 \mathrm{bB}$ & $924 \mathrm{aA}$ & \\
\hline & \multicolumn{4}{|c|}{ Live stem mass $\left(\mathrm{kg} \mathrm{ha}^{-1}\right.$ of DM) } & \\
\hline Beginning & $1,205 \mathrm{bB}$ & $1,070 \mathrm{bB}$ & $1,469 \mathrm{aA}$ & $1,035 \mathrm{bB}$ & \multirow{4}{*}{21.9} \\
\hline Middle & $1,321 \mathrm{aB}$ & $1,020 \mathrm{bB}$ & $1,476 \mathrm{aA}$ & $1,147 \mathrm{bB}$ & \\
\hline End & $1,577 \mathrm{aA}$ & $1,383 \mathrm{bA}$ & $969 \mathrm{cB}$ & $1,713 \mathrm{aA}$ & \\
\hline & \multicolumn{4}{|c|}{ Dead leaf lamina mass $\left(\mathrm{kg} \mathrm{ha}^{-1}\right.$ of DM) } & \\
\hline Beginning & $210 \mathrm{aB}$ & $74 \mathrm{bB}$ & $205 \mathrm{aB}$ & $92 \mathrm{bB}$ & \multirow{3}{*}{4.7} \\
\hline Middle & $246 \mathrm{aAB}$ & $109 \mathrm{bB}$ & $288 \mathrm{aAB}$ & $102 \mathrm{bB}$ & \\
\hline End & $\begin{array}{l}310 \mathrm{bA} \\
\text { Tiller } \mathrm{m}^{-2}\end{array}$ & $390 \mathrm{bA}$ & $328 \mathrm{bA}$ & $483 \mathrm{aA}$ & \\
\hline Beginning & $715 \mathrm{aA}$ & $637 \mathrm{bC}$ & $618 \mathrm{bA}$ & $636 \mathrm{bB}$ & \multirow{3}{*}{3.7} \\
\hline Middle & $730 \mathrm{aA}$ & $707 \mathrm{aB}$ & $565 \mathrm{cB}$ & $647 \mathrm{bB}$ & \\
\hline End & $750 \mathrm{bA}$ & $782 \mathrm{bA}$ & $665 \mathrm{cA}$ & $892 \mathrm{aA}$ & \\
\hline
\end{tabular}

*SEM: standard error of the mean; Means followed by the same lowercase letter in the row and upper case in the column do not differ by the Tukey test $(\mathrm{P}>0.05)$.

In the short, short/mown and tall/mown pastures the live stem mass (LSM) increased from the beginning to the end of the grazing period, what was contrary to that observed for the tall pasture. In the beginning of the grazing period, LSM was bigger for the tall pasture. In the middle of the grazing period, LSM was bigger in the short and tall pastures than in the mowed pastures. In the end of the grazing period, LSM was bigger in short and tall/mown pastures, intermediate in short/mown pasture and lower in the tall pasture (Table 3).

In all pastures, the dead leaf lamina mass (DLLM) was bigger in the beginning of the grazing period than in the end (Table 3 ). This same pattern of response occurred for the bulk density of dead leaf (Table 4).

Table 4. Bulk density of morphological components in marandu palisadegrass pastures during the grazing period in spring and summer and according to the sward condition during late winter

\begin{tabular}{|c|c|c|c|c|c|}
\hline \multirow[b]{2}{*}{ Grazing period } & \multicolumn{4}{|c|}{ Sward condition at late winter } & \multirow[b]{2}{*}{$\mathrm{EM}^{*}$} \\
\hline & Short & Short/mown & Tall & Tall/mown & \\
\hline & \multicolumn{5}{|c|}{ Live leaf lamina bulk density (kg ha.cm ${ }^{-1}$ of dray matter - DM) } \\
\hline Beginning & $336 \mathrm{bA}$ & $363 \mathrm{bA}$ & $448 \mathrm{aA}$ & 305bA & \multirow{3}{*}{9} \\
\hline Middle & $292 b B$ & $332 \mathrm{bA}$ & $429 \mathrm{aA}$ & $273 \mathrm{bA}$ & \\
\hline \multirow[t]{2}{*}{ End } & $144 \mathrm{bC}$ & $203 \mathrm{bB}$ & $165 \mathrm{bB}$ & $298 \mathrm{aA}$ & \\
\hline & \multicolumn{5}{|c|}{ Live stem bulk density ( $\mathrm{kg}$ ha. $\mathrm{cm}^{-1}$ of DM) } \\
\hline Beginning & $299 \mathrm{bC}$ & $307 \mathrm{bB}$ & $376 \mathrm{aB}$ & $281 \mathrm{bB}$ & \multirow{3}{*}{1} \\
\hline Middle & $362 \mathrm{bB}$ & $313 \mathrm{bB}$ & 476baA & $312 \mathrm{bB}$ & \\
\hline \multirow[t]{2}{*}{ End } & $544 \mathrm{aA}$ & $507 \mathrm{aA}$ & $349 \mathrm{bB}$ & $552 \mathrm{aA}$ & \\
\hline & \multicolumn{5}{|c|}{ Dead leaf lamina bulk density ( $\mathrm{kg}$ ha. $\mathrm{cm}^{-1}$ of DM) } \\
\hline Beginning & $52 \mathrm{aB}$ & $21 \mathrm{bB}$ & $52 \mathrm{aB}$ & $25 \mathrm{bB}$ & \multirow{3}{*}{4} \\
\hline Middle & $67 \mathrm{abAB}$ & $33 \mathrm{bB}$ & $93 \mathrm{aA}$ & $28 \mathrm{bB}$ & \\
\hline End & $107 \mathrm{bA}$ & $143 a A$ & 118abA & $156 \mathrm{aA}$ & \\
\hline
\end{tabular}

*SEM: standard error of the mean; Means followed by the same lowercase letter in the row and upper case in the column do not differ by the Tukey test $(\mathrm{P}>0.05)$.

In the beginning and middle of the grazing period, the DLM was bigger in short and tall pastures than in the mowed pastures. In the end of this period, the tall/mown pasture presented bigger DLLM than the others (Table 3). 
The tiller number (TN) did not vary during the grazing period in the short pasture. In short/mown pasture, the $\mathrm{TN}$ increased from the beginning to the end of the grazing period. In the tall pasture, the $\mathrm{TN}$ was lower in the middle than in the beginning and end of the grazing period. In the tall/mown pasture, the $\mathrm{TN}$ was lower in the beginning and middle than in the end of the grazing period. In the beginning of the grazing period, the short pastures presented bigger TN. In the middle of the grazing period, the short and short/mown pastures continued to have a bigger $\mathrm{TN}$ value, in comparison to the other pastures, the tall pasture presented lower value for this characteristic. In the end of the grazing period, the lowest TN occurred in the tall pasture, while the tall/mown pasture showed bigger TN (Table 3).

\section{DISCUSSION}

The average sward height was similar in all pastures $(33.6 \mathrm{~cm})$, since they were managed with the same criterion, which was the same sward height range $(20$ to $40 \mathrm{~cm})$, according to the recommendations of $\mathrm{Da}$ Silva et al. (2013). However, due to the need to keep at least two sheep per paddock, the average sward height decreased in the end of the grazing period, probably due to the low pasture growth, caused by the decrease in rainfall in the last two months of the grazing period (Figure 1).

The tall pasture presented worse morphological composition during the grazing period, in the spring and early summer (Table 1), due to the high amount of dead material present in this pasture, originally from the previous winter. In addition, it is possible that this large amount of dead material has caused bigger shading at the base of the plants, which may have inhibited the development of basal buds in new tillers in the tall pasture (SANTANA et al., 2014). This fact may have contributed to the low leaf area index (LAI) of the tall pasture (Table 1).

On the other hand, the two mowed pastures presented better morphology, characterized by lower mass and bulk density of dead stem (Table 1) and lower mass and bulk density of dead leaf lamina at the beginning and middle of the grazing period (Tables 3 and 4) than the other pastures. This occurred probably because the mowing provided the elimination of dead material from the winter (Table 1), as observed by Souza et al. (2015) in a study with marandu palisadegrass.

In general, mowing is performed only on tall pastures and with high forage mass in the end of winter in order to improve the pasture morphology in the spring, which was proven in our study. However, even in the short pasture, the mowing also promoted the improvement of pasture morphology (Table 1).

From the beginning to the end of the grazing period, the morphology of the pasture worsened, being characterized by the reduction of the mass and bulk density of the live leaf lamina in the short, short/mown and tall pastures (Tables 3 and 4); increase of mass and bulk density of live stem in short/mown pasture (Tables 3 and 4); and increase of masses and bulk densities of dead stem (Table 2) and dead leaf lamina (Tables 3 and 4). Possibly, the young tillers that emerged in the early spring were developed during the grazing period, becoming older, especially in the short/mown pastures during late winter. The old tiller shows a worse morphological composition than the young tiller, which is conformity with the results of Santos et al. (2018). These authors observed that the weight and percentage of live stems from old tillers were bigger in relation to young tillers; the percentage of live leaf lamina was bigger in young tiller $(52.6 \%)$ and lower in old tiller $(21.3 \%)$; and the percentage of dead leaf lamina was bigger in the old than in young tillers.

In a study conducted with marandu palisadegrass in continuous stocking, Paiva et al. (2012) verified that the old tillers, those with more than four months of age, had a longer stem and a larger number of senescent leaves than the young tillers, less than two months old. Thus, the bigger relative participation of older tillers at the end of the grazing period may have compromised the pasture morphology. In addition, as already reported, the reduction of sward height at end of grazing period may also have been responsible for the decrease in LAI of the pastures (Table 2).

In the tall pasture, there was a lot of live stem still coming from winter. This large amount of stem may have served as a substrate for the appearance of aerial tillers at the beginning and middle of the grazing period. This may have contributed to the increase in mass and bulk density of live leaf lamina on tall grass (Tables 3 and 4). In this context, Santos et al. (2014) verified that the relative participation of aerial tillers (430 tillers $\mathrm{m}^{-2}$ ) was $18 \%$ in the total population of tillers of Urochloa decumbens cv. Basilisk in the spring, after deferred grazing.

In addition, due to the large amount of old forage (stems plus dead material) present in the tall pasture during late winter, it is possible that the tillers that appeared in this spring grass were 
developed in a more shaded environment. In this condition, it is common for tillers to have bigger stem and leaf elongation rates (PAULA et al., 2012). This fact could also justify the increases of the masses and the bulk densities of live leaf lamina and live stem in the tall pasture from the beginning to the middle of the grazing period (Tables 3 and 4).

At the end of the grazing period, probably many old and longer-stemmed tillers had died, which would justify the lower mass and bulk density of live stem, as well as the increase in mass and bulk density of dead leaf lamina on tall pasture (Tables 3 and 4). This same argument can also be the cause of the increase of mass and bulk density of dead stem in pastures at the end of grazing period (Table 2).

The tiller number was bigger in the short pasture than in the others during the beginning of the grazing period (Table 3 ), because probably the plants in this pasture received more light at their base. Thus, many basal buds may have developed into tillers, a typical process of the early spring (SBRISSIA et al., 2010; DA SILVA; SBRISSIA; PEREIRA, 2015), where climatic conditions (rainfall and temperature - Figure 1) are again favorable to plant growth.

In the middle of the grazing period, besides the short pasture, the short/mown pasture also presented a high tiller number, when compared to the other pastures (Table 3). This indicates that, after the short pasture, the short/mown pasture was the one that had the fastest recovery of the tiller population after winter. Otherwise, the tall pasture was the one with the lowest tiller number in the middle and end of the grazing period (Table 3 ). This demonstrates that tall pasture took longer to reach the high population density of tillers common in spring. This delay in tillering of tall pasture may have been due to the lower incidence of light at the base of the plants, caused by the large amount of dead material in this forage canopy (SANTANA et al., 2014).

The expectation that the tall/mown pasture presents less tillering, due to the shading of the basal buds caused by the deposition of forage mowed, have not been confirmed. The tall/mown pasture presented bigger tiller number than the tall pasture in the middle of the grazing period. In addition, by the end of this period, the tall/mown pasture also had the greatest tiller number than the tall pasture (Table 3).

These results indicate that other mechanisms, in addition to light, may be acting to stimulate the emergence of tillers in the tall/mown pastures, such as plant reserve stocking and hormonal factors. In this sense, with mowing, many tillers had their apical meristem eliminated and thus, the synthesis of hormones responsible for apical dominance may have decreased (SANTOS et al., 2014). In this condition, the tillering is stimulated (MATTHEW et al., 2000). In addition to this fact, it is also possible that marandu palisadegrass had a high stock of reserve compounds during late winter, because the grass growth is low at this season and so is the demand for these compounds (DA SILVA et al., 2014; FERRO et al., 2015).

The tall pasture showed high bulk densities of forage morphological components (Tables 1 and 4), even with low tiller number during the beginning and middle of the grazing period (Table 3 ). This happened because in the tall pasture, there was a great amount of dead tiller, still coming from the previous winter, which raised the bulk densities of dead stem and dead leaf lamina. In addition, in the tall pasture, despite having few tillers (Table 3), these probably were older and had longer length, which may have contributed to the higher bulk density of live stem at the beginning of the grazing period (Table 4). Thus, as already reported, this large amount of old forage in the tall pasture during the beginning of the grazing period may have increased competition for light in the canopy, making the tillers heavier. This may have contributed to the bigger leaf and stem bulk densities in the tall pasture during the beginning and middle of the grazing period (Table 4).

\section{CONCLUSIONS}

In comparison to short pasture, tall marandu palisadegrass pasture during the late winter presents worse sward structure in the spring than During late winter, the mowing of pasture and the height reduction of the marandu palisadegrass pasture improves the sward structure in the spring and summer.

RESUMO: A estrutura do pasto é importante porque influencia as respostas de plantas e animais em condições de pastejo. O objetivo com este trabalho foi avaliar as características estruturais do pasto de capimmarandu (Brachiaria brizantha syn. Urochloa brizantha) durante a primavera e o verão, em função da condição do pasto no fim do inverno. Quatro condições de pasto no fim do inverno foram avaliadas: baixo $(24,1 \mathrm{~cm})$, baixo $(25,2 \mathrm{~cm}) /$ roçado $(8 \mathrm{~cm})$, alto $(49,0 \mathrm{~cm})$ e alto $(50,0 \mathrm{~cm}) /$ roçado $(8 \mathrm{~cm})$. O índice de área foliar 
foi menor no pasto alto do que no pasto alto/roçado. A massa e a densidade volumétrica de colmo morto foram maiores no pasto alto, intermediárias no pasto baixo, e inferiores nos pastos roçados. No início do período de pastejo, a massa de colmo vivo foi maior no pasto alto. No início e meio do período de pastejo, a densidade volumétrica de lâmina foliar morta foi menor nos pastos roçados. No início do período de pastejo, o pasto baixo apresentou maior número de perfilho (NP). No meio do período de pastejo, os pastos baixo e baixo/roçado tiveram maior NP. No fim do período de pastejo, o menor valor de NP ocorreu no pasto alto. O pasto alto no fim do inverno apresenta estrutura desfavorável ao animal em pastejo, enquanto que a roçada e a redução da altura do capim-marandu melhora a estrutura do pasto na primavera e no verão.

PALAVRA-CHAVE: Brachiaria brizantha syn. Densidade volumétrica da forragem. Índice de área foliar. Massa de forragem. Número de perfilho. Urochloa brizantha.

\section{REFERÊNCIAS}

ALVARES, C. A.; STAPE, J. L.; SENTELHAS, P. C; GONÇALVES, J. L. M.; SPAROVEK, G. Köppen's climate classification map for Brazil. Meteorologische Zeitschrift, v. 22, n. 6, p. 711-728, 2013.

https://doi.org/10.1127/0941-2948/2013/0507

CARVALHO, P. C. F.; BREMM, C.; MEZZALIRA, J. C.; FONSECA, L.; DA TRINDADE, J. K.; BONNET, O. J. F.; TISCHLER, M.; GENRO, T. C. M.; NABINGER, C.; LACA, E. A. Can animal performance be predicted from short-term grazing processes? Animal Production Science, v. 55, n. 3, p. 319-327, 2015. https://doi.org/10.1071/AN14546

COSTA, L. K. P.; SANTOS, M. E. R.; SILVA, G. P.; CARVALHO, B. H. R.; PESSOA, D. D.; GALZERANO, L.; SILVA, N. A. M. Reduction of sward height in the fall/winter as strategy to optimize tillering in Urochloa brizantha syn. Brachiaria brizantha. Archivos de Zootecnia, v. 65, n. 252, p. 499-506, 2016.

DA SILVA, S. C.; GIMENES, F. M. A.; SARMENTO, D. O. L.; SBRISSIA, A. F.; OLIVEIRA, D. E.; HERNADEZ-GARAY, A.; PIRES, A. V. Grazing behaviour, herbage intake and animal performance of beef cattle heifers on marandu palisade grass subjected to intensities of continuous stocking management. Journal of Agricultural Science, v. 151, n. 5, p. 727-739, 2013. https://doi.org/10.1017/S0021859612000858

DA SILVA, S. C.; PEREIRA, L. E. T.; SBRISSIA, A. F.; HERNANDEZ-GARAY, A. Carbon and nitrogen reserves in marandu palisade grass subjected to intensities of continuous stocking management. Journal of Agricultural Science, v. 1, n. 1, p. 1-15, 2014

DA SILVA, S. C.; SBRISSIA, A. F.; PEREIRA, L. E. T. Ecophysiology of C4 forage grasses: understanding plant growth for optimising their use and management. Agriculture, v. 5, n. 3, p. 598-625, 2015.

https://doi.org/10.3390/agriculture5030598

FERRO, M. M.; ZANINE, A. M.; FERREIRA, D. J.; SOUZA, A. L.; VALÉRIO GERON, L. J. Organic Reserves in tropical Grasses under Grazing. American Journal of Plant Sciences, v. 6, n. 14, p. 2329-2338, 2015. https://doi.org/10.4236/ajps.2015.614236

MATTHEW, C.; ASSUERO, S. G.; BLACK, C. K.; SACKVILLE HAMILTON, N. R. Tiller dynamics of grazed swards. In: LEMAIRE, G.; HODGSON, J.; MORAES, A.; CARVALHO, P. C. F.; NABINGER, C. (Ed.). Grassland ecophysiology and grazing ecology. Wallingford: CABI, 2000. p.127-150. https://doi.org/10.1079/9780851994529.0127

MOTT, G. O.; LUCAS, H. L. The design, conduct, and interpretation of grazing trials on cultivated and improved pastures. In: INTERNATIONAL GRASSLAND CONGRESS, 6, 1952, Pennsylvania. Proceedings... Pennsylvania: State College Press, 1952. p. 1380-1385. 
NELSON, C. J. Shoot Morphological Plasticity of Grasses: Leaf Growth vs. Tillering. In: LEMAIRE, G.; HODGSON, J.; MORAES, A.; NABINGER, C.; CARVALHO, P. C. F. Grassland ecophysiology and grazing ecology. CAB-International, Wallingford, UK, 2000, p.101-126, 2000.

https://doi.org/10.1079/9780851994529.0101

PAIVA, A. J.; DA SILVA, S. C.; PEREIRA, L. E. T.; GUARDA, V. D.; MESQUITA, P.; CAMINHA, F. O. Structural characteristics of tiller age categories of continuously stocked marandu palisade grass swards fertilized with nitrogen. Revista Brasileira de Zootecnia, v. 41, n. 1, p. 24-29, 2012. https://doi.org/10.1590/S1516-35982012000100004

PAULA, C. C. L.; EUCLIDES, V. P. B.; LEMPP, B.; BARBOSA, R. A.; MONTAGNER, D. B.; CARLOTO, M. N. Acúmulo de forragem, características morfogênicas e estruturais do capim-marandu sob alturas de pastejo. Ciência Rural, v. 42, n. 11, p. 2059-2065, 2012. https://doi.org/10.1590/S0103-84782012005000084

PEDREIRA, B. C.; PEDREIRA, C. G. S. Fotossíntese foliar do capim-xaraés [Brachiaria brizantha (A. Rich.) Stapf. cv. Xaraés] e modelagem da assimilação potencial de dosséis sob estratégias de pastejo rotativo. Revista Brasileira de Zootecnia, v. 36, n. 4, p. 773-779, 2007. https://doi.org/10.1590/S1516-35982007000400004

PEREIRA, L. E. T.; MESQUITA, P.; DA SILVA, S. C.; PAIVA, A. J.; CAMINHA, F.; GUARDA, V. D.; NASCIMENTO JR., D. Structural characteristics of marandu palisadegrass swards subjected to continuous stocking and contrasting rhythms of growth. Scientia Agricola, v. 67, n. 1, p. 23-30, 2010. https://doi.org/10.1590/S0103-90162010000100004

PEREIRA, L. E. T.; HERLING, V. R.; AVANZI, J. C.; DA SILVA, S. C. Morphogenetic and structural characteristics of signal grass in response to liming and defoliation severity. Pesquisa Agropecuaria Tropical, v. 48, n. 1, p. 1-11, 2018. https://doi.org/10.1590/1983-40632018v4849212

PERI, P. L.; MOOT, D. J.; MCNEIL, D. L.; LUCAS, R. J. Modelling net photosynthetic rate of fi eld-grown cocksfoot leaves to account for regrowth duration. New Zealand Journal of Agricultural Research, v. 46, n. 2, p. 105-115, 2003. https://doi.org/10.1080/00288233.2003.9513536

PESSOA, D. D.; SILVA, N. A. M.; CARVALHO, B. H. R.; CARDOSO, R. C.; SILVA, G. P.; SANTOS, M. E. R. Tillering of Marandu palisadegrass maintained at fixed or variable heights throughout the year. Tropical Grasslands, v. 4, n. 2, p. 101-111, 2016. https://doi.org/10.17138/TGFT(4)101-111

SANTANA, S. S.; FONSECA, D. M.; SANTOS, M. E. R.; SOUSA, B. M. L.; GOMES, V. M.; NASCIMENTO JR, D. Initial height of pasture deferred and utilized in winter and tillering dynamics of signal grass during the following spring . Acta Scientiarum. Animal Sciences, v. 36, n. 1, p. 17-23, 2014. https://doi.org/10.4025/actascianimsci.v36i1.20463

SANTOS, M. E. R.; CASTRO, M. R. S.; GOUVEIA, S. C.; GOMES, V. M.; FONSECA, D. M.; SANTANA, S. S. Contribuição de perfilhos aéreos e basais na dinâmica de produção de forragem do capim-braquiária após o pastejo diferido. Bioscience Journal, v. 30, n. 3, p. 242-430, 2014.

http://www.seer.ufu.br/index.php/biosciencejournal/article/view/18023

SANTOS, M. E. R.; CARVALHO, B. H. R.; COSTA, L. K. P.; PESSOA, D. D.; FERNANDES, W. B. O manejo da desfolhação utilizado no inverno modifica a estrutura vertical do capim-marandu no verão subsequente. Enciclopédia Biosfera, v. 11, n. 21, p. 3526-3534, 2015.

SANTOS, M. E. R.; SIMPLICIO, M. G.; SILVA, G. P.; OLIVEIRA, H. A.; COSTA, L. K. P.; SOUZA, D. O. C. Reduction of sward height in the fall and winter as a strategy to improve the structure of marandu palisadegrass ( syn. cv. Marandu). Tropical Grasslands, v. 5, n. 3, p. 143-152, 2017.

https://doi.org/10.17138/TGFT(5)143-152 
SANTOS, M. E. R.; AVILA, A. B.; CARVALHO, A. N.; ROCHA, G. O.; CLEEF, F. S. V.; SEGATTO, B. N.; VASCONCELOS, K. A.; PEREIRA, R. S. Marandu palisade grass management strategies at the beginning of the deferment period and effects on tillering. Semina - Ciências Agrárias, v. 39, n. 4, p. 1617-1626, 2018. https://doi.org/10.5433/1679-0359.2018v39n4p1617

SBRISSIA, A. F.; SILVA, S. C.; SARMENTO, D. O. L.; MOLAN, L. K.; ANDRADE, F. M. E.

GONÇALVES, A. C.; LUPINACCI, A. V. Tillering dynamics in palisadegrass swards continuously stocked by cattle. Plant Ecology, v. 206, p. 349-359, 2010. https://doi.org/10.1007/s11258-009-9647-7

SOUSA, D. O. C.; SANTOS, M. E. R.; FONSECA, D. M.; MACEDO JR, G. L.; SILVA, S. P. Sheep production during the rainy season in marandu palisadegrass swards previously utilized under deferred grazing. Arquivo Brasileiro de Medicina Veterinária e Zootecnia, v. 70, n. 2, p. 1-8, 2018.

https://doi.org/10.1590/1678-4162-9414

SOUZA, D. O. C.; FERNANDES, W. B.; FERNANDES, G.; SANTOS, M. E. R.; SILVA, S. P. A roçada do capim-marandu alto no fim do inverno melhora a estrutura do pasto no início do verão. Enciclopédia Biosfera, v. 11, n. 21, p. 12-22, 2015.

THORNTHWAITE, C. W.; MATHER, J. R. The water balance. Centerton, NJ: Drexel Institute of Technology - Laboratory of Climatology, 1955. 104p. (Publications in Climatology, vol. VIII, n.1).

WOLFINGER, R. Covariance structure selection in general mixed models. Communications in Statistics Simulation, v.22, n.4, p.1079-1106, 1993. https://doi.org/10.1080/03610919308813143 